\title{
Non-complementation and Recessiveness as Properties of Missense Suppressor Genes in the Fungus Coprinus
}

\author{
By N. K. TODD* AND LORNA A. CASSELTON \\ Department of Plant Biology and Microbiology, Queen Mary College, \\ University of London, London E I 4 NS \\ (Received 3I January 1973; revised I 2 March 1973) \\ SUMMARY
}

\begin{abstract}
Mutations in the $a c u-I$ gene which lead to inability to use acetate as sole carbon source have been used to select recessive $s u^{+}$gene mutations. Of five $a c u-I$ alleles tested, two, designated $a c u-I-2$ and $a c t-I-4$, were suppressible. At least three different $s u^{+}$genes suppressed the $a c u-I-2$ mutation and two $s u^{+}$genes suppressed the acu-I-4 mutation. All five $s u^{+}$mutations are completely allele specific and will only suppress the acu-I mutation for which they were selected. On a glucose medium, where $s u^{+}$activity is not required for growth, presence of a $s u^{+}$gene depresses the growth rate. These two facts suggest that the $s u^{+}$genes act by causing translation errors. Although individually each $s u^{+}$gene is recessive in a $\mathrm{su}^{+} / \mathrm{su}$ heterozygote, any two $\mathrm{su}^{+}$genes in a double heterozygote do not complement. Recessiveness and non-complementation are considered as properties of missense $s u^{+}$genes involving modified tRNA species and interpreted in terms of $s u^{+} \mathrm{tRNA}$ concentrations.
\end{abstract}

\section{INTRODUCTION}

Non-complementation is generally indicative that mutations are in the same gene. The first report of non-complementation between non-allelic mutations came from the work of Lewis (I96I) on certain recessive suppressor $\left(s u^{+}\right)$gene mutations in the fungus Coprinus lagopus. Subsequently, Morgan (1966) described further examples of non-complementation in this fungus and again these involved recessive $s u^{+}$gene mutations. Now that suppression is better understood, non-complementation is no longer a puzzling phenomenon, but suggests an important genetic criterion which will define a particular type of suppressor mechanism.

It has been shown that many $s u^{+}$gene mutations in bacteria act by altering the specificity of one of the components required for protein biosynthesis (see reviews by Gorini, 1970: Casselton, 1971). This is known as informational suppression because the consequences of the original mutation are corrected as a result of mistranslation of messenger RNA. The best known and probably the commonest informational suppressors give rise to altered transfer RNA molecules which mistranslate one or more particular codons. Mistranslation is itself very specific; the modified tRNA acquires a new codon specificity and generally loses its original specificity. In the case of a tyrosine tRNA which translates the UAG chain-terminating codon, this change in specificity is the result of a single base substitution in the anticodon (Goodman, Abelson, Landy, Brenner \& Smith, 1968). tRNA suppressors can be classed as missense or nonsense (chain-terminating) suppressors depending on the codon they translate. More recently evidence has been obtained for tRNA suppressors of frameshift mutations (Riddle \& Roth, 1972). The codon specificity of tRNA means that

\footnotetext{
* Present address: Department of Environmental Sciences, Plymouth Polytechnic, Plymouth PL4 8AA.
} 
these suppressor genes are allele specific - they can only suppress alleles of a mutant gene involving the same (or an alternative) codon.

Informational suppressors have been found in fungi also. The super-suppressors in the yeast Saccharomyces cerevisiae are analogous to nonsense suppressors in bacteria (Hawthorne \& Mortimer, 1963, 1968). There is now direct evidence from the amino acid sequence studies on iso-I-cytochrome $c$ that certain super-suppressors specifically translate either the UAA or the UAG chain-terminating codons (Stewart et al. 1972; Stewart \& Sherman, 1972). Apart from allele specificity, super-suppressors have another important property; in $\mathrm{Su}^{+} / \mathrm{su}^{-}$ heterozygotes, the $s u^{+}$(suppressed) phenotype is expressed, therefore $s u^{+}$appears to be dominant to its wild-type $s u^{-}$allele. This is to be expected since $s u^{+}$tRNA, in acquiring a new translation function, does not compete for expression with $s u^{-}$tRNA, but with the chainterminating mechanism in the ribosome and this is the same in both diploid and haploid cells.

Missense suppressor genes have so far received little attention in fungi. We have suggested that the recessiveness and non-complementation observed by Lewis and Morgan for $s u^{+}$ genes in Coprinus would be predictable properties of missense tRNA suppressors (Todd \& Casselton, 1972). This is based on the argument that, whilst $s u^{+}$tRNA does not compete with its corresponding $s u^{-}$tRNA, it has to compete with the tRNAs specified by one or more other genes which normally translate the mutant codon. In the heterozygous diploid $s u^{+} / s u^{-}$there is still only one gene for $s u^{+}$tRNA, but now two for each of the tRNAs with which it competes, so that the relative amount of $s u^{+} \mathrm{tRNA}$ is approximately halved. If the $s u^{+} \mathrm{tRNA}$ is not efficient, its activity may no longer be expressed and $s u^{+}$will appear to be recessive. In a diploid carrying two different $s u^{+}$genes which can suppress the same gene mutation, however, the ratio of $s u^{+}$tRNA to the tRNA with which it competes will be the same as in a haploid cell with either one of the $s u^{+}$genes. The suppressor activity should therefore be expressed, leading to apparent non-complementation.

To test these predictions, we selected recessive, allele specific $s u^{+}$gene mutations which could then be tested in heterozygotes for complementation. This paper describes two sets of $s u^{+}$genes which combine the three properties we were looking for.

\section{METHODS}

\section{Strains}

acu-I mutants are unable to grow on a medium containing acetate as sole carbon source but can grow normally on a glucose medium. Mutants have been induced in two standard wild-type strains using either $N$-methyl- $N^{\prime}$-nitro- $N$-nitrosoguanidine (NG) or ultraviolet light irradiation (u.v.). Coprinus lagopus (C. cinereus, Pinto-Lopes \& Almeida, I972) has a tetrapolar mating type control. To satisfy the mating type restrictions on dikaryon formation and fruiting, original mutants were crossed to wild-type strains so that certain of the acu-I alleles could be recovered in monokaryons of compatible mating type. Details of $a c u-I$ strains used are given in Table $\mathrm{I}$.

Other mutants. Auxotrophic mutations were introduced into acu-I strains to provide forcing markers for selection of diploids. The following mutations were used; $a d-3, a d-5$, ad-8, met- 1 , met-5 and nic-4 imposing growth requirements for adenine, methionine and nicotinamide respectively. 
Table 1. acu-I mutants

\begin{tabular}{|c|c|c|c|c|}
\hline Strain & $\begin{array}{c}\text { Allele } \\
\text { designation }\end{array}$ & $\begin{array}{l}\text { Mating } \\
\text { type }\end{array}$ & Origin & Mutagen \\
\hline \multicolumn{5}{|l|}{ Original } \\
\hline CCI & ach-I-I & А 6 в 6 & $\mathrm{H} 9^{*}$ & $\mathrm{NG}$ \\
\hline $\mathrm{CC} 3$ & $a c d 1-1-2$ & А $6 \mathrm{~B} 6$ & H9 & $N G$ \\
\hline $\mathrm{CCI} 2$ & acu-I-3 & A $6 \mathrm{~B} 6$ & H9 & $N G$ \\
\hline $\mathrm{CC} 2 \mathrm{O}$ & $a c u-1-4$ & A $6 \mathrm{~B} 6$ & $\mathrm{H} 9$ & $N G$ \\
\hline UVAI & actu-I- 6 & A5B5 & $\mathrm{TC4}_{4}^{*}$ & U.V \\
\hline \multicolumn{5}{|l|}{ Derived } \\
\hline CCI.OI & $a c t i-I-I$ & A $5 B 5$ & $\mathrm{CCI} \times \mathrm{HI}^{*}$ & $\cdots$ \\
\hline $\mathrm{CC} 3 . \mathrm{OI}$ & ach $1-1-2$ & A5B 5 & $\mathrm{Cc}_{3} \times \mathrm{TC}_{4}$ & - - \\
\hline $\mathrm{CC} 20.0 \mathrm{I}$ & acu-I-4 & A5B 5 & $\mathrm{CC} 2 \mathrm{O} \times \mathrm{TC}_{4}$ & - \\
\hline UVAIOI & acu-I-6 & А 6 B 6 & LVAI $\times H 9$ & - - \\
\hline
\end{tabular}

* Strains $\mathrm{H} 9$ and HI were isolated from a fruit body collected in the wild by D. Lewis. TC4 was derived from a cross between two other strains obtained from this fruit body, $\mathrm{H} 5$ and $\mathrm{H} 2$.

\section{Culture}

Glucose medium was the minimal medium used by Lewis (1961) with the addition of $0.25 \mathrm{~g} \mathrm{MgSO}_{4} / 1$ (Casselton \& Casselton, 1966). The acetate medium is described by Casselton \& Condit (1972). When required, growth supplements were added as follows: $100 \mathrm{mg}$ L-methionine/l, $100 \mathrm{mg}$ adenine sulphate/l and $20 \mathrm{mg}$ nicotinamide/l. All cultures were incubated in the dark at $37^{\circ} \mathrm{C}$ except for fruiting which requires a lower temperature $\left(26^{\circ} \mathrm{C}\right)$ and light.

\section{Techniques}

General techniques for using Coprinus have been described by Lewis (196I). Common $A$ diploid strains were selected from appropriate common $A$ heterokaryons by the method of Casselton (1965). Growth was measured by recording colony radius over a period not exceeding 8 days. Data for each culture represented the mean readings from three colonies.

\section{Selection of acu+ revertants from acu-I strains}

Spontaneous. The uninucleate asexual spores, oidia, were harvested from 5-day-old cultures grown on glucose medium and either sown directly on to acetate medium or, alternatively, first sown on to glucose medium and then overpoured with acetate medium after $48 \mathrm{~h}$ of incubation. This latter technique allowed a larger number of nuclei to be screened since the oidia had each germinated to give a number of cells. Any $a c u^{+}$colonies appeared within 5 days of exposure to acetate medium.

Induced. Oidial suspensions were irradiated with ultraviolet light to give 0.03 to $0.0 \mathrm{I}^{\circ}$, survival before plating out as above. All $\mathrm{acu}^{+}$revertants were subsequently maintained on acetate medium.

\section{RESULTS}

To demonstrate allele specificity, the important genetic criterion of a translational suppressor, it was necessary to select for $\mathrm{su}^{+}$genes of mutations in a gene for which many alleles were available. For this reason $a c u-I$ mutants were chosen. The $a c u-I$ gene maps approximately five units from the $A$ mating type locus and is thought to be the structural gene for acetyl CoA synthetase (Casselton \& Casselton, in preparation). Details of five acu-I mutants used for selection of $s u^{+}$mutations are given in Table I. $a c u-I-2$ was chosen 
Table 2. Identification of $\mathrm{su}^{+}$gene mutations which suppress acu-I-2 and acu-I-4 by crossing acu+ revertants to a wild-type strain*

\begin{tabular}{|c|c|c|c|c|c|c|}
\hline $\begin{array}{l}\qquad a c u-I \\
\text { allele } \\
\text { suppressed }\end{array}$ & $\begin{array}{l}\text { Suppressor } \\
\text { designation }\end{array}$ & $\begin{array}{c}\text { Viability } \\
\text { basidiospores } \\
\left(\begin{array}{l}0 \\
0\end{array}\right)\end{array}$ & $\begin{array}{c}\text { Total } \\
\text { progeny }\end{array}$ & $\begin{array}{c}a c u^{-} \\
\text {progeny }\end{array}$ & $\begin{array}{c}\text { Recombination } \\
\text { between } s u^{+} \\
\text {and } a c u-1 \\
\left(0_{0}^{\circ}\right)\end{array}$ & $\begin{array}{l}\text { Probability } \\
\text { of } 3: \mathrm{I} \\
\text { ratio }\end{array}$ \\
\hline \multirow[t]{7}{*}{$a c t 1-1-2$} & $S U-I 2 I$ & $86 \cdot 1$ & I 12 & 22 & $39 \cdot 3$ & 0.2 \\
\hline & $s u-I 22$ & $91 \cdot 9$ & I 57 & 32 & $40 \cdot 8$ & 0.2 \\
\hline & $s u-I 27$ & $73 \cdot 8$ & 128 & 25 & 39.0 & 0.15 \\
\hline & $s u-123$ & $82 \cdot 4$ & 253 & 39 & $30 \cdot 8$ & $<0.001$ \\
\hline & $s u-125$ & $94 \cdot 5$ & 274 & 42 & $30 \cdot 6$ & $<0.001$ \\
\hline & $s U-124$ & $90 \cdot 7$ & 167 & 43 & free & 0.89 \\
\hline & $s u-126$ & 87.6 & 270 & 69 & free & 0.90 \\
\hline \multirow[t]{2}{*}{$a c u-I-4$} & $s u-I 4 I$ & $9 I \cdot 4$ & 185 & 40 & $43 \cdot 3$ & 0.29 \\
\hline & $s u-I 42$ & $96 \cdot 4$ & 115 & 13 & $22 \cdot 6$ & $<0.001$ \\
\hline
\end{tabular}

* The wild-type strain was TC4 in all crosses except that involving $5 u-142$ which was crossed to $\mathrm{H} 9$.

because it is leaky and therefore likely to be a missense mutation. The other mutations are non-leaky and obviously different from $a c u-I-2$.

In selecting for suppression, we were interested only in $s u^{+}$gene mutations which were recessive. It was necessary also to obtain more than one $s u^{+}$gene capable of suppressing the same $a c u-I$ mutation so that complementation tests could be carried out.

\section{Identification of suppressor gene mutations}

Since the $s u^{+}$mutation and the mutation it suppresses are in different genes, the two mutations must be separable by recombination at meiosis. Thus if the suppressed mutant $\left(a c u-I s u^{+}\right)$is crossed to a wild-type strain $\left(a c u^{+} s u^{-}\right)$the original mutant phenotype ( $\left.a c u-I s u^{-}\right)$ will be recovered in the progeny. This is the only genotype which is distinguishable since the other progeny classes $\left(a c u^{+} s u^{-}, a c u^{+} s u^{+}\right.$and $\left.a c u-I s u^{+}\right)$will be phenotypically wild-type $\left(a c u^{+}\right)$. If there is no linkage between the $s u^{+}$gene and the $a c u-I$ gene, then the expected phenotypic ratio is $3 \mathrm{acu}^{--}$to $\mathrm{r} \mathrm{acu}^{-}$. If the $s u^{+}$gene is linked to $a c u-I$, then the percentage of $a c u^{-}$progeny will be less than $25 \%$, and since the $a c u^{-}$progeny represent half the recombinant progeny, the distance between the two genes can be calculated. Absence of $a u^{-}$progeny indicates either intragenic suppression, which would not be detected in small progeny samples, or back mutation.

Of the five $a c u-I$ alleles tested, only $a c u-I-2$ gave spontaneous revertants. These were obtained by the overpour technique which precluded measuring the reversion frequency. $a c u-I-I$ failed to give revertants, whereas those obtained from $a c u-I-3$ and $a c u-I-6$ failed to give $a c u^{-}$progeny in crosses to wild-type and were classed as back mutations. The $a c u^{+}$ revertants of the other two alleles, $a c u-I-2$ and $a c u-I-4$, all gave $a c u^{-}$progeny when crossed to wild-type showing that reversion was caused by $s u^{+}$gene mutations (see Table 2).

To carry out complementation tests, we needed at least two different $s u^{+}$genes which could suppress the same allele. This important requirement is satisfied for suppressors of both $a c u-I-2$ and $a c u-I-4$. The recombination data indicate that there are at least two, and possibly three, distinct $s u^{+}$genes of the $a c u-I-2$ mutation. One of these $s u^{+}$genes is linked to the $a c u-I$ locus, giving $30 \%$ recombination, and a second shows free recombination. The possible third $s u^{+}$gene shows loose linkage to $a c u-I$ ( 39 to $40 \%$ recombination). Obviously the best test of non-identity of this third $s u^{+}$gene with the one which shows free recombination would be to cross the different suppressed mutants together. This would result in $a u^{-}$ 
Table 3. Allele specificity of acu-I-2 and acu-I-4 su ${ }^{+}$genes.

$s u-I 2 I, s u-123$ and $s u-I 26$ are $s u^{+}$genes of $a c u-I-2 ; s u-I 4 I$ and $s u-I 4^{2}$ are $s u^{+}$genes of $a c u-I-4$

\begin{tabular}{|c|c|c|c|c|c|c|}
\hline \multirow{3}{*}{$\begin{array}{l}a c u-I \\
\text { allele }\end{array}$} & \multirow{3}{*}{$\begin{array}{c}s u^{+} \\
\text {gene }\end{array}$} & \multirow{3}{*}{$\begin{array}{c}\text { Viability } \\
\text { basidio- } \\
\text { spores } \\
(\%)\end{array}$} & & & \multicolumn{2}{|c|}{ Expected $a c u^{+}$if $s u^{+}$} \\
\hline & & & \multicolumn{2}{|c|}{ Progeny } & \multirow{2}{*}{$\begin{array}{c}\text { Allele } \\
\text { specific } \\
\text { (probability) }\end{array}$} & \multirow{2}{*}{$\begin{array}{c}\text { Allele } \\
\text { unspecific } \\
\text { (probability) }\end{array}$} \\
\hline & & & $a c u^{-}$ & $a c u^{\div}$ & & \\
\hline \multirow[t]{5}{*}{ achl-I-I } & $S U-I 2 I$ & $91 \cdot 0$ & 99 & 46 & $44 \cdot 0(0 \cdot 70)$ & $72.5(<0.001)$ \\
\hline & $s u-I 23$ & $97 \cdot 3$ & 82 & 46 & $44 \cdot 3(0.75)$ & $64 \cdot 0(0 \cdot 002)$ \\
\hline & $s u-126$ & $92 \cdot 3$ & 98 & 34 & $33.0(0.90)$ & $66 \cdot 0(<0.001)$ \\
\hline & $s u-I 4 I$ & $91 \cdot 6$ & 115 & 48 & $46 \cdot 2(0.75)$ & $8 \mathrm{I} \cdot 5(<0.001)$ \\
\hline & $s u-142$ & 93.4 & 62 & 37 & $38 \cdot 3(0 \cdot 80)$ & $49 \cdot 5(0.012)$ \\
\hline \multirow[t]{4}{*}{$a c u-I-6$} & $S H-I 2 I$ & $93 \cdot 6$ & I 2 I & 49 & $51 \cdot 6(0 \cdot 66)$ & $85^{\circ} 0(<0.001)$ \\
\hline & $s u-123$ & $96 \cdot 5$ & 57 & 38 & $32.9(0.28)$ & $47.5(0.05)$ \\
\hline & $s u-126$ & $89 \cdot I$ & 139 & 44 & $45 \cdot 75(0.75)$ & $91 \cdot 5(<0.001)$ \\
\hline & $S U-I 4 I$ & $86 \cdot 3$ & $9 \mathrm{I}$ & 34 & $35.4(0.80)$ & $62.5(<0.001)$ \\
\hline \multirow[t]{3}{*}{$a c u-I-4$} & $S U-I 2 T$ & $88 \cdot 9$ & 133 & 53 & $56.5(0.58)$ & $93.0(<0.001)$ \\
\hline & $s 1 t-123$ & $89 \cdot 3$ & 87 & 49 & $47 \cdot 1(0 \cdot 73)$ & $68 \cdot 0(0.00 \mathrm{I})$ \\
\hline & $s u-126$ & $9 I \cdot 9$ & 85 & 29 & $28.5(0.98)$ & $57.0(<0.001)$ \\
\hline$a c u-I-2$ & $s u-142$ & $87 \cdot 5$ & 84 & 55 & $53.8(0.85)$ & $69.5(0.014)$ \\
\hline
\end{tabular}

progeny if the $s u^{+}$genes are non-allelic. All the $s u^{+}$mutations were selected in the same strain (CC3) and close linkage of the $a c u-I$ gene to the $A$ mating type locus has made it impossible to recover the $s u^{+}$genes in strains of compatible mating type. However, all crosses were to the same wild-type strain and the high viability of the basidiospores (see Table 2) precludes genetic background and inviability distorting the recombination frequencies. It therefore, seems probable that there are three distinct $s u^{+}$genes of $a c u-I-2$ and mutations designated $s u-I 2 I, s U-I 23$ and $s u-I 26$ were chosen as representing these three genes. Only two $a c u^{+}$revertants were obtained from act-I-4 strains, but these proved to be mutations in separate genes based on the very different recombination frequencies with acu-I $\left(43.3^{\circ}\right.$, and $22.6 \%$ ). These two $s u^{+}$genes were designated $s u-I 4 I$ and $s u-I 42$ respectively. Whilst it was possible in this case to make a cross between the suppressed mutants in an attempt to confirm non-identity of the $s u^{+}$genes, the cross was sterile.

\section{Recessiveness}

A rapid test of the $s u^{+}$genes for dominance was made by forming dikaryons between each of the suppressed mutants and a strain carrying the unsuppressed $a c u-I-I$ mutation. The genotype of these dikaryons was $\left(a c u-I s u^{+}\right)+\left(a c u-I s u^{-}\right)$. If $s u^{+}$is recessive, the dikaryon will be unable to grow on acetate medium whereas if it is dominant, the dikaryon will be able to grow on this medium. All five $\mathrm{Su}^{+}$genes were recessive by this test. Subsequently this was confirmed in $a c u-I-2$ and $a c u-I-4$ homoallelic heterozygotes (see later).

\section{Allele specificity of suppressor genes}

Whilst a single missense suppressor tRNA has the potential to suppress more than one gene mutation, it can only do so if the mutations involve the same (or an alternative) codon. The four $a c u-I$ alleles used to test allele specificity are unlikely to be the same because $a c u-I-2$ is leaky, whereas $a c u-I-4$ is not, and the other two alleles, $a c u-I-I$ and $a c u-I-6$, were induced by different mutagens (see Table 1 ).

Each of the suppressed mutants was crossed to strains carrying one of the three other $a c u-I$ alleles. Amongst the progeny, each allele will be recovered with the $s u^{+}$gene and each 
allele with the $s u^{-}$gene. If the $s u^{+}$gene is allele unspecific and can suppress both alleles, half the progeny will have the $a c u^{+}$phenotype (one parental and one recombinant class). On the other hand, if the $s u^{+}$gene is allele specific, then only the one parental class will be $a c u^{+}$. The percentage of $a c u^{+}$progeny will depend on the linkage between the $s u^{+}$gene and the $a c u-I$ locus (see Table 2.)

All five $s u^{+}$genes were tested for ability to suppress $a c u-I-I$ and all but one (which failed to fruit) for ability to suppress $a c u-I-6$. In all the crosses the number of $a c u^{+}$progeny is less than half indicating that the $s u^{+}$genes cannot suppress either $a c u-I-I$ or $a c u-I-6$ (see Table 3 ). This is not surprising since we failed to obtain suppressors of these two mutations in selection experiments. Column 6 of Table 3 gives the numbers of $a c u^{+}$progeny expected in each cross if the $\mathrm{Su}^{+}$gene is allele specific. These numbers are very close to the numbers of $\mathrm{acu}^{+}$ progeny obtained. Particularly interesting are the crosses in which the three $a c u-I-2 s u^{+}$ genes were tested for ability to suppress $a c u-I-4$ and one of the $a c u-I-4 s u^{+}$genes was tested for ability to suppress $a c u-I-2$. The results show that each $\mathrm{Su}^{+}$gene is completely allele specific and can only suppress the $a c u-I$ allele for which it was selected.

\section{Non-complementation}

With two sets of recessive allele specific suppressor genes identified, it was possible to test for complementation. Three doubly heterozygous $s u^{+}$combinations were possible with three $a c u-I-2 s u^{+}$genes and one for the two $a c u-I-4 s u^{+}$genes. All these heterozygous combinations grew well on acetate medium and since this required expression of the recessive $s u^{+}$mutations it was apparent that the $s u^{+}$gene mutations do not complement.

Complementation tests were carried out in dikaryons for $a c u-I-4 s u^{+}$genes and in diploids with $a c u-1-2 s u^{+}$genes. There is no evidence that complementation occurs more efficiently when structural genes of proteins are combined in a single diploid nucleus compared with separate haploid nuclei in a dikaryon (Casselton \& Lewis, 1967; Day \& Roberts, I969). At one time (Pontecorvo, 1963) it was considered that non-complementation between $\mathrm{su}^{+}$ genes might be an effect of separation in different nuclei of the dikaryon, but the present results show that this is not true.

Non-complementation between different $s u^{+}$genes is best illustrated in terms of radial growth of heterozygotes on acetate medium. At the same time, the recessiveness of each $\mathrm{su}^{+}$ gene was demonstrated in strains heterozygous for the single $s u^{+}$gene and homoallelic for the $a c u-I$ allele.

acu-I-4 Strains. Fig. I (a) compares the growth of acu-I-4 haploid monokaryons on acetate medium. The unsuppressed $a c u-I-4$ mutant cannot grow; su-I $4 I$ and $s u-I 42$ restore ability to use acetate with different efficiency. The $s u-I 4 I$ strain grows almost as well as an $a c u^{+}$ wild-type strain but the su-I 42 strain grows much more slowly.

Fig. I (b) compares the growth of $a c u-I-4$ dikaryons on acetate medium. When either $s u^{+}$ gene is made heterozygous, the $s u^{+}$gene is no longer expressed and there is little or no growth. Although neither of these $s u^{+} / s u^{-}$dikaryons can grow, the doubly heterozygous dikaryon with both $s u^{+}$genes grows well and we therefore observe non-complementation between $S U-I 4 I$ and $s u-I 42$.

acu-I-2 Strains. Fig. $2(a)$ compares the growth of acu-I-2 haploid monokaryons on acetate medium. $a c u-I-2$ is a leaky mutation, note the slow growth of the unsuppressed mutant. $s u-I 2 I$ and $s u-I 23$ restore growth on acetate to much the same extent, but not to the level of the $a c u^{+}$strain. The $s u-I 26$ strain grows more slowly than the other $s u^{+}$strains but better than the unsuppressed mutant.

All the $s u^{+} / s u^{-}$heterozygous diploids grow slowly on acetate (see Fig. $2 b$ ). This is ex- 


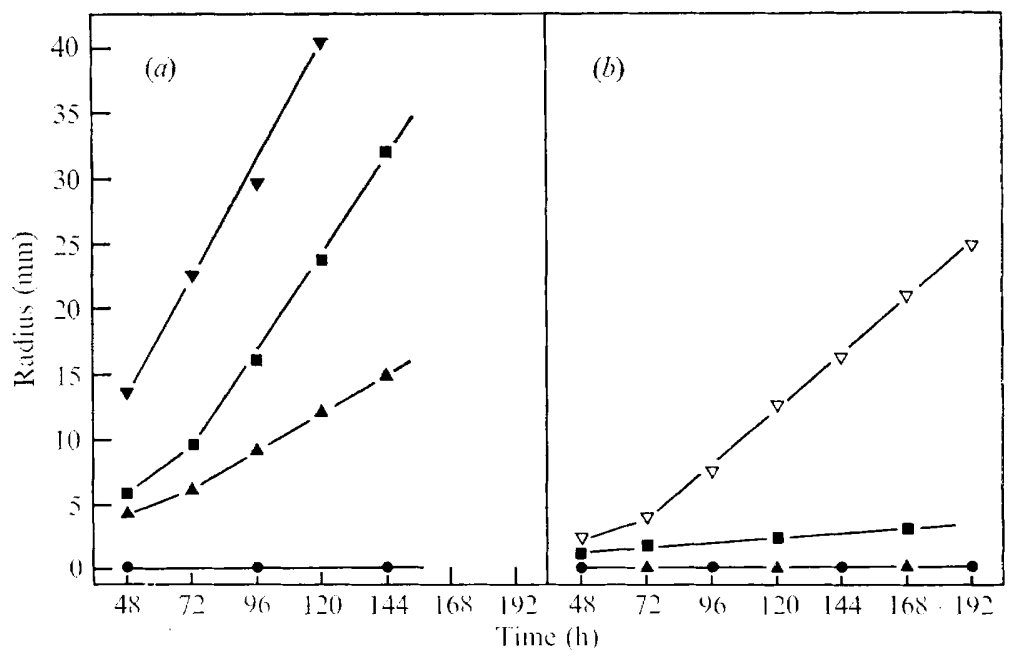

Fig. 1. Growth of $a c u-I-4$ and suppressed $a c u-I-4$ strains on acetate medium. (a) Haploid monokaryons. $\nabla, a c u^{-} s u^{-} ; \mathbf{Q}, a c u-I-4 s u-I 4 I ; \mathbf{A}, a c u-I-4 s u-I 42 ; 0, a c u-I-4 s u^{-}$. (b) Dikaryons. Homozygous: $-s u^{-}$. Heterozygous: $\mathbf{\square}$, st $/ s u-141 ; \mathbf{A}, s u / s u-142$. Doubly heterozygous: $\square$, $s u^{-}\left|s t-I 4 I s u^{-}\right| s u-I 42$. Values plotted are the average of triplicate tests.

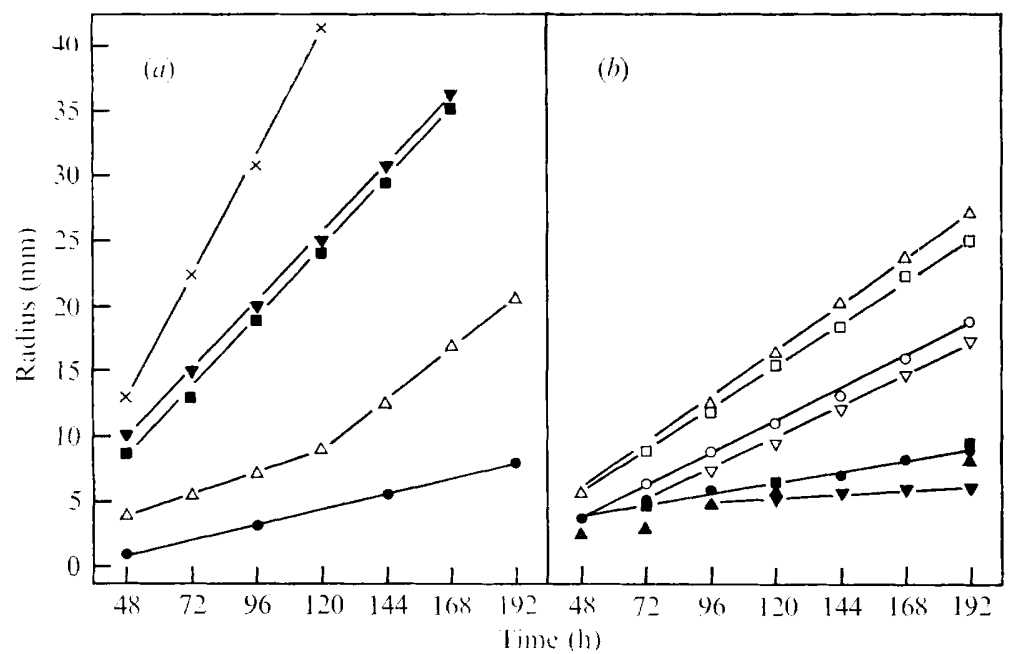

Fig. 2. Growth of $a c u-I-2$ and $a c u-I-2$ suppressed strains on acetate medium. (a) Haploid monokaryons. $\times, a c u^{+} s u^{-} ; 0, a c u-I-2 s u^{-} ; \nabla, a c u-I-2 s u-I 2 I ; \square, a c u-I-2 ~ s u-I 23 ; \Delta, a c u-I-2$ su-I26.

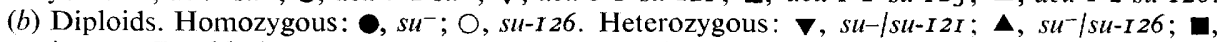
$s u^{-} / s u-123$. Doubly heterozygous: $\triangle, s u^{-} / s u-I 2 I s u^{-} / s u-I 26 ; \square, s u^{-} / s u-I 2 I ~ s u^{-} / s u-I 23 ; \nabla, s u^{-} / s u^{-}$ $123 \mathrm{st}^{-} / \mathrm{st}-\mathrm{I} 26$. Values plotted are the average of triplicate tests.

pected because $a c u-I-2$ is leaky and the $s u^{+}$genes are recessive. However, all the doubly heterozygous diploids grow well. A growth test on a diploid homozygous for su-I26 gave a measure of how much growth to expect of a diploid strain in which the $s u^{+}$genes are expressed. This homozygous su-I26 diploid grows as well as the haploid su-I26 monokaryon, as expected since the ratio of $s u^{+}$tRNA to tRNA with which it competes should be the same in 
Table 4. Growth rates of suppressed and unsuppressed strains on glucose medium

\begin{tabular}{|c|c|c|}
\hline & $\begin{array}{l}\text { Radial growth } \\
\text { (rate } \mathrm{mm} / \text { day) }\end{array}$ & $\begin{array}{l}\text { Wild-type } \\
\text { growth rate }(\%)\end{array}$ \\
\hline \multicolumn{3}{|l|}{$a c u-I-2$ strains } \\
\hline$a c u^{+} s u^{-}$ & $9.35 \pm 0.24$ & 100 \\
\hline$a c u^{\prime}-I^{-2} s u^{-}$ & $9 \cdot 20 \pm 0 \cdot 27$ & $98 \cdot 4$ \\
\hline acu-I-2 SU-I $2 I$ & $5 \cdot 75 \pm 0 \cdot 14$ & $61 \cdot 5$ \\
\hline acu-1-2 su-123 & $8 \cdot 20 \pm 0.35$ & $87 \cdot 7$ \\
\hline$a c t-1-2$ su-I 26 & $6 \cdot 30 \pm 0 \cdot 21$ & $67 \cdot 3$ \\
\hline \multicolumn{3}{|l|}{ acu- $I-4$ strains } \\
\hline$a c u^{+} s u^{-}$ & $9.55 \pm 0.48$ & 100 \\
\hline$a c u-I-4 s u^{-}$ & $9.50 \pm 0.44$ & $99 \cdot 4$ \\
\hline$a c u-I-4 s u-I 4 I$ & $7.90 \pm 0.81$ & $82 \cdot 7$ \\
\hline$a c u-I-4 s u-142$ & $7 \cdot 50 \pm 0.25$ & $78 \cdot 5$ \\
\hline$a c u^{+} \operatorname{su}-I 4 I$ & $7.90 \pm 0.21$ & $82 \cdot 7$ \\
\hline
\end{tabular}

both strains. The homozygous $s u^{+}$diploid grows as well as the $s u-123 / s u-126$ double heterozygote and less well than either of the other doubly heterozygous diploids. Noncomplementation between these recessive suppressor gene mutations is again apparent. The results with $a c u-I-2 s u^{+}$strains rule out a trans position effect causing non-complementation because in two cases $(s u-12 I / s u-126$ and $s u-123 / s u-126)$ the heterozygous diploid nuclei contain unlinked $s u^{+}$genes.

\section{Effect of su+ gene mutations on growth}

A property of missense $s u^{+}$genes, first observed in Neurospora crassa by Yanofsky (I952), is that the $\mathrm{su}^{+}$gene in the absence of the mutation it suppresses, depresses the growth of an otherwise wild-type strain. The modified tRNA which corrects a gene mutation by mistranslating a particular codon will mistranslate this same codon elsewhere. In the absence of the mutation it suppresses, or on a medium where the mutant protein is no longer required, the $s u^{+}$gene is obviously disadvantageous.

The detrimental effect of $a c u-I s u^{+}$gene mutations can be measured by comparing the growth rate of unsuppressed and suppressed strains on glucose medium where acetyl CoA synthetase is not required for growth and the $a c u^{+}$wild-type and $a c u-I$ mutants are expected to grow equally well. Since growth of the $a c u-I$ mutants is no longer dependent on $s u^{+}$gene activity, any reduction in growth rate of $s u^{+}$strains compared to $s u^{-}$strains is due entirely to the presence of the $s u^{+}$genes.

As expected, the unsuppressed $a c u-I-2$ and $a c u-I-4$ strains grow as well as the $a c u^{+}$ strain. In all cases, the $s u^{+}$gene leads to a reduction in the growth rate. This is particularly marked in the case of $s U-I 2 I$ and $s u-I 26$ where the growth rate is less than $70 \%$ of that of the wild-type or unsuppressed $a c u-I$ mutant.

Included in the growth tests is an $a c u^{+}, s u-I 4 I$ strain in which the $s u^{+}$gene is now present in the absence of the mutation which it suppresses. This was recovered from a cross between the $a c u-I-4 s u-I, I$ strain and a wild-type strain. Presence of the $s u-I 4 I$ gene was confirmed by backcrossing to the original unsuppressed $a c u-I-4$ mutant and obtaining the expected ratio of $a c u^{+}$to $a c u^{-}$progeny. The $s u-I 4 I$ mutation depresses growth of an otherwise wild-type strain (see Table 4 ). The fact that the $s u^{+}$gene mutations do depress growth, is good evidence that they are acting during translation. 


\section{DISCUSSION}

The suppressor genes described have three properties predicted of missense $s u^{+}$genes specifying modified tRNA species with altered codon specificities (Todd \& Casselton, 1972). First, they are allele specific, the $s u^{+}$genes which suppress one allele cannot suppress any of the other alleles tested. Secondly, when any one of the $s u^{+}$genes is made heterozygous in either a dikaryon or a diploid, the suppressor mutation is either not expressed, or so poorly as to appear to be recessive. Thirdly, when two different $s u^{+}$genes are combined in a double heterozygote, the suppressor phenotype is maintained, hence we observe non-complementation. The terms recessive and non-complementation do not have the conventional meaning in this context since the phenotype of these heterozygotes has been interpreted as effects of $s u^{+}$tRNA concentrations. They are retained because they describe the growth responses one observes by making the standard genetic tests.

If the ability to grow on acetate was directly proportional to the $s u^{+} t$ RNA concentration then $s u^{+} / s u^{-}$heterozygotes should grow at approximately half the rate of the $s u^{+}$haploid strains rather than not at all (and hence $s u^{+}$appearing recessive). It is likely, however, that it requires a threshold level of suppressed protein before the $a c u^{+}$phenotype can be expressed. Fig. I shows that the homozygous $s u^{-}$dikaryon does not grow on acetate medium, but the heterozygous $s u-I 4 I / s u^{-}$dikaryon grows slowly and this is only possible if there is $s u^{+}$ activity.

The allelic specificity of the $a c u-I s u^{+}$genes and their detrimental effect on the growth of strains carrying them is good evidence that they act by causing translation errors. Modified ribosomes as well as tRNA molecules have been implicated in translational suppression, but a ribosomal mechanism seems unlikely in the present study because of the number of $\mathrm{Su}^{+}$genes involved. In Escherichia coli only two gene mutations have been described which constitute ribosomal $s u^{+}$genes (Apirion, 1966; Rosset \& Gorini, I969), whereas there are a large number of tRNA $s u^{+}$genes.

There are two ways in which the suppressor mutation may result in altered tRNA molecules. The mutation may occur in the structural gene for the tRNA, or it may occur in another gene and lead to loss of function of an enzyme which modifies tRNA. The latter would be recessive, since in $s u^{+} / s u^{-}$heteozygotes the enzyme function would be restored and mutations in different genes would show normal complementation. We have postulated that missense $s u^{+}$mutations in the tRNA structural genes of fungi are also recessive (as probably are frameshift tRNA $s u^{+}$genes). This is because the effective $s u^{+} t$ RNA concentration in the heterozygotes is halved compared with the tRNA species with which it has to compete. In bacteria, dominance of the $s u^{+}$mutation is taken as evidence that it is in the tRNA structural gene. This is true of missense $s u^{+}$genes as well as nonsense and frameshift $s u^{+}$genes. It must be remembered, however, that heterozygosity in dominance tests in bacteria is limited to a small region of the chromosome around the $s u^{+}$locus and this is unlikely to include genes for those tRNAs with which the missense $s u^{+}$tR NA competes. In fungi, the whole genome is doubled in heterozygotes, and hence all tRNA genes. We suggest that a unique property which defines missense $s u^{+}$mutations in the tRNA structural genes of fungi is noncomplementation.

Missense suppression is an interesting phenomenon because it is surprising that it occurs at all. The suppressor tRNA which mistranslates a mutant codon to correct a gene error creates new errors by mistranslating the same codon in messenger RNA from other nonmutant genes. It would seem essential that missense suppressor efficiency is low in order to minimize the amount of faulty protein synthesized as a consequence of its activity. If the 
efficiency of the $s u^{+}$tRNA is very low, it is likely that in multimeric proteins, the function of a small number of correct polypeptides produced by suppression will be lost if aggregated with a predominating number of mutant polypeptides. This factor would not affect the results in the present study because the $a c u-I$ enzyme appears to function as a single polypeptide chain. The acu-.I locus is the only structural gene for the enzyme acetyl CoA synthetase and amongst 26 differently isolated mutants we have failed to observe any interallelic complementation (Casselton \& Casselton, in preparation).

Strictly speaking, efficiency of a $s u^{+}$gene is measured as the amount of suppressed to unsuppressed protein synthesized. Efficiency is not only determined by the amount of $s u^{+}$ tRNA in the cell, but may also be affected by a greatly lowered aminoacylation rate for the mutationally altered tRNA (Carbon \& Curry, 1968; Squires \& Carbon, 197I).

Of the two $a c u-I-4 \mathrm{Su}^{+}$genes, the one which restores faster growth on acetate medium appears more efficient than the other, but it may be that the slower growing strain has more active $s u^{+}$tRNA. Efficient mistranslation of the mutant codon in the $a c u-I$ gene would be counteracted by more general mistakes in total cell protein synthesis, hence an overall depression in growth. However, how well the suppressed mutant grows on acetate may not only be a reflexion on $s u^{+}$tRNA efficiency but on how the mutant codon is translated. The two different $s u^{+}$genes may cause insertion of different amino acids at the mutant site and one amino acid may be more acceptable in the acu-I protein than the other.

An important consequence of understanding the activity of tRNA suppressors is that it has provided a technique for identifying the structural genes for tRNA. Of particular interest is the redundancy that has been shown to exist in genes for tRNAs that translate the same codon, and also the marked difference in the relative amounts of these tRNAs specified by different genes. Most of the tRNAs implicated in suppression in Escherichia coli represent apparently dispensable species which are normally present in the cell in small amount.

Studies with super-suppressors in yeast indicate that there is even greater redundancy of tRNA genes in eukaryotic cells. For example, a $s u^{+}$mutation may occur in as many as eight different genes to give translation of the UAA codon as tyrosine (Gilmore, Stewart \& Sherman, 1968). By analogy with studies in Escherichia coli this suggests that there must be at least eight genes for tyrosine tRNA in yeast. It is not known whether the products of these genes are present in unequal amounts as is true of three genes for tyrosine tRNA in E. coli, (Goodman et al. 1968). Selection for recessive missense $\mathrm{su}^{+}$genes in haploid fungal cells is a way of identifying a wide variety of genes for apparently dispensable tRNA species. What the normal function of such dispensable species of tRNA is and how many dispensable species exist in eukaryotic cells are obviously interesting questions and by continuing to study missense suppression we hope to find some answers.

A maintenance grant from the Science Research Council to N.K.T. is gratefully acknowledged.

\section{REFERENCES}

ApIRION, D. (I966). Altered ribosomes in a suppressor strain of Escherichia coli. Journal of Molecular Biology I6, 285-30I.

CARbon, J. \& Curry, J. B. (1968). Genetically and chemically derived missense suppressor tRNAs with altered enzymic aminoacylation rates. Journal of Molecular Biology 38, 20I-2 I6.

CAsselton, L. A. (1965). The production and behaviour of diploids of Coprinus lagopus. Genetical Research 6 , I90-208.

Casselton, L. A. (1971). Suppressor genes. Science Progress 59, 143-160. 
Casselton, L. A. \& Cassel.ton, P. J. (1966). Control of fruiting of Coprinus lagopus on certain synthetic media. Transactions of the British Mycological Society 49, 579-58r.

Casselton, L. A. \& Condit, A. (1972). A mitochondrial mutant of Coprinus lagopus. Journal of General Microbiology 72, $52 \mathrm{I}-527$.

CAsselton, L. A. \& Lewis, D. (1967). Dilution of gene products in the cytoplasm of heterokaryons in Coprinus lagopus. Genetical Research 9, 63-71.

DAY, P. R. \& Roberts, C. F. (1969). Complementation in diakryons and diploids of Coprimus lagopus. Genetics 62, 265-270.

Gilmore, R. A., Stewart, J. W. \& Sherman, F. (1968). Amino acid replacements resulting from supersuppression of a nonsense mutant of yeast. Biochimica et biophysica acta I6r, 270-272.

Goodman, H. M., Abelson, J., Landy, A., Brenner, S. \& Smith, J. D. (1968). Amber suppression: a nucleotide change in the anticodon of a tyrosine transfer RNA. Nature, London 217, 1019-1024.

Gorini, L. (1970). Informational suppression. Annual Reviews of Genetics 4, 107-I 34.

HaWthORNe, D. C. \& Mortimer, R. K. (I963). Super-suppressors in yeast. Genetics 48, 61 7-620.

HAWTHORNE, D. C. \& MORTIMER, R. K. (I968). Genetic mapping of nonsense suppressors in yeast. Genetics 6o, $735-742$.

LEwIS, D. (1961). Genetical analysis of methionine suppressors in Coprinus. Genetical Research 2, I4I-I55.

Morgan, D. H. (1966). Suppression of 'purple' in Coprinus lagopus - an anomalous genetic situation. Genetical Research 7, 195-206.

Pinto-Lopes, J. \& Almeida, M. G. (1972). 'Coprinus lagopus', a confusing name as applied to several species. Portugaliae acta biologica (B) II, I67-204.

PonteCORvo, G. (1963). Microbial genetics; retrospect and prospect. Proceedings of the Royal Society B 158, $1-23$.

Riddle, D. L. \& Roth, J. R. (1972). Frameshift suppressors III. Effects of suppressor mutations on transfer RNA. Journal of Molecular Biology 66, 495-506.

Rosset, R. \& GorinI, L. (1969). A ribosomal ambiguity mutation. Journal of Molecular Biology 39, 95-1 12.

SQuires, C. \& Carbon, J. (1971). Normal and mutant glycine transfer RNAs. Nature New Biology 233, 274-277.

Stewart, J. W. \& Sherman, F. (1972). Demonstration of UAG as a nonsense codon in Bakers' yeast by amino-acid replacements in iso-I-cytochrome c. Journal of Molecular Biology 68, 429-443.

Stewart, J. W., Sherman, F., Jackson, M., Thomas, F. L. \& Shipman, N. (1972). Demonstration of the UAA ochre codon in bakers' yeast by amino-acid replacements in iso-I-cytochrome c. Jotrinal of Molecular Biology 68, 83-96.

TODD, N. K. \& CASSELTON, L. A. (1972). Non-complementation between recessive suppressor gene mutations in Coprinus lagopus. Heredity $\mathbf{2 8 ,} 274$.

YANOFSKY, C. (1952). The effects of gene change on tryptophan desmolase formation. Proceedings of the National Academy of Sciences of the United States of America 38, 215-226. 